\title{
The Essence of the Upanishad in T. S. Eliots Poems and Plays
}

\author{
--Damaru Chandra Bhatta \\ Associate Professor of English, \\ Tri-Chandra Campus, Tribhuvan University, \\ Kathmandu, Nepal \\ Email: damarubhatta@gmail.com
}

\section{DOI: https://doi.org/10.3126/litstud.v34i01.39520}

\section{Abstract}

This paper attempts to explore the essence of the principal Upanishads of the Hindu philosophy in T. S. Eliot's selected seminal poems and plays. The principal Upanishads are the Ishavasya, Kena, Katha, Prashna, Mundaka, Mandukya, Taittiriya, Aitareya, Chhandogya, Brihadaranyaka and Shvetashvatara. The famous poems are "AshWednesday" and Four Quartets, and the famous plays are Murder in the Cathedral, The Family Reunion, and The Cocktail Party under scrutiny in this paper. The essence of the principal eleven Upanishads is that Brahman is source of all creations including the human beings, who get results according to their karma and are born again and again until they get moksha (liberation) through the self-realization of Brahman; therefore, our goal should be to attain moksha or Brahman, only through which we can experience perpetual peace and unbound bliss. Likewise, Eliot suggests that we should attempt to go back to our "Home" (Brahman, also a symbol of peace and bliss), for which we must attempt several times until we become qualified through the non-dual knowledge of "the still point" (Brahman) and its self-realization along with the spiritual practices of renunciation and asceticism. The practice of unattached action done without the hope of its fruit (nishkam karma) and unselfish devotion (Bhakti) are secondary paths to attain liberation. Since the path of spiritual knowledge can make us realize Brahman immediately, Eliot prefers this path of knowledge to the progressive or indirect paths of action and devotion. Thus, his texts reflect the essence of the Upanishads. The significance of this paper within the context of existing scholarship lies in its introduction to the new knowledge that Eliot's poems and plays could be extensively interpreted by finding the essence of the Upanishads in his texts. Practically, the knowledge of the essence of the Upanishads can help us know the mystery of life and death, and Atman and Brahman, and get liberation from all kinds of suffering and misery, and the cycle of life and death as well before death. 
Keywords: Atman, Brahman, Essence, Liberation, Non-Dual, Oneness, Rebirth, Realization, Wheel.

\section{Introduction}

Eliot (1888-1965) is a prominent literary figure in English literature since the 1920s. He was a student at Harvard between 1906 and 1914. He studied the oriental subjects like the Upanishad, the Bhagavad- Gita, the Patanjali Yoga Sutras, andBuddhism along with Sanskrit and Pali languages. There is a philosophical and spiritual closeness between the thoughts of Eliot and those of the Hindu philosophy, especially the Upanishad. He himself explicitly acknowledged his poetic debt to "Indian thought and sensibility" (Oldmeadow 30). He is one of the Western writers and philosophers who helped spread the importance of the Vedic philosophy in the West through his literature. He is a great visionary and global poet who found a spiritual language and connected East and West by transcending the traditional divisions between their thoughts. His famous poems and plays, which are under scrutiny of this paper, reflect the essence of the Upanishad of the Hindu philosophy. Indicating Eliot's high respect towards the Hindu philosophy, Jeffrey M. Perl and Andrew P. Tuck comment that "T. S. Eliot wrote (1933) that the great philosophers of India 'make most of the great European philosophers look like schoolboys"' (115).

The principal Upanishads of the Hindu philosophy are: Ishavasya, Kena, Katha, Prashna, Mundaka, Mandukya, Taittiriya, Aitareya, Chhandogya, Brihadaranyaka and Shvetashvatara. These Upanishads convey four core spiritual concepts. ${ }^{1}$ They are: the existence of Atman and Brahman, the oneness between Atman and Brahman, rebirth according to one's karma, and the ultimate goal of the attainment of liberation and (the non-dual) Brahman through the immediate path of spiritual knowledge. In this context, F. Max Muller says without hesitation, "The greatest contribution of Indian philosophy to the world is the concept of 'Brahman' and since 'Atman' is present in every human being the unification of 'Atman' with 'Brahman' is the ultimate goal of every living being" (19). The four core concepts of the principal Upanishads are found in Eliot's poems and plays. His writings

\footnotetext{
${ }^{1}$ The ideas of the Upanishads mentioned throughout this paper are from $\mathrm{S}$. Radhakrishnan's book The Principal Upanishads, and Swami Gambhirananda's book Eight Upanishads: With the Commentary of Shankaracharya, vol. I \& II.
} 
show that he aspires to achieve the highest goal of life, that is, to be united with Brahman in his Self while living alive.

\section{Objectives}

(1) To explore the essence of the Upanishad in Eliot's two poems "AshWednesday" (1930) and Four Quartets (1936-1942) comprising of four parts ("Burnt Norton,"“East Coker,"“The Dry Salvages," and "Little Gidding"), and three famous plays Murder in the Cathedral (1935), The Family Reunion (1939), and The Cocktail Party (1949).

(2) To reflect on the significance of that essence of the Upanishad in his selected writings.

The Essence of the Upanishad in Eliot's Poems and Plays Eliot's poems and plays show the essence of the principal Upanishads of the Hindu philosophy. Eliot presents the karma theory by using the word "Wheel" ${ }^{2}$," which is a major symbol of rebirth as per karma and of briefness and futility of human life as well. Suggesting this message, Fourth Tempter tells Archbishop Thomas Becket in Murder in the Cathedral, "That nothing lasts but the wheel turns" (1.192). The image of "the Wheel" is found in the ShevetashvataraUpanishad, which expresses that five sense objects ("panchaavartaam") are the whirlpools and by being tied to them, the jiva (individual creature) moves on the wheel of life and death (1.5). According to Eliot Weinberger, there is a close relationship between karma, vasana and, rebirth. "Vasana, which literally means "scent," is karmic residue, the stuff as ineffable as a smell - that remains from a past life. Each life produces vasanas, which remain dormant until one is reincarnated in the same species" (52).

The Chorus in Murder in the Cathedral makes us mindful of the ephemerality of the human life, "Dust I am, to dust am bending / From the final doom impending / Help me, Lord, for death is near" (2.211). Dust implies mortal human body. This reminds us of the saying of the Brihadaranyaka Upanishadthat our body is turned into ashes by fire one day- "bhasmaantam shareeram" (5.15.1). Clay is symbolic of death. Only death is true in the world. In this regard, the Chhandogya Upanishad boldly declares that clay alone is truth-"mritika iti eva satyam" (6.1.4). Here, the clay represents Brahman, the Absolute truth, and the first cause of the creation of the universe. Likewise, the expression of the KathaUpanishad is very relevant here. It declares that human being is subject to decay and death- "jeeryanmartyah"(1.1.28). The constant internalization of life's frailty and fleetingness can make us grow wise so that we could go beyond materiality in order to realize the Essence.

\footnotetext{
${ }^{2}$ In this article, all the quotations of T. S. Eliot are taken from his book The Complete Poems and Plays: 1909-1950
} 
When we get the light of knowledge, we are free from the darkness of ignorance and attain the liberation through knowledge while alive (jnanamukti, jivan mukti, or sadyo mukti) and become free from the cycle of life and death instantly. We need not wait for the liberation after death (videha mukti).In this spirit, Harry teaches Agatha in The Family Reunion:

HARRY. The chain breaks,

The wheel stops, and the noise of machinery,

And the desert is cleared, under the judicial sun [spiritual knowledge]

Of the final eye, and the awful evacuation

Cleanses. (2.2.277)

"The chain" or the link between life, death, and rebirth breaks when "the wheel" or karma and its result end through "the final eye" of knowledge. The knowledge "cleanses" the terrible "evacuation" or the dirt of mind. The dirt of mind is ignorance.

In "Dry Salvages" III, Eliot reiterates the message of Lord Krishna to the great warrior Arjuna as in the Bhagavad-Gita8.6 that our rebirth is conditioned by our desire or thought made at the last time of death: "You can receive this: 'on whatever sphere of being / The mind of a man may be intent / At the time of death. ..." (134). The Chorus of townswomen in Murder in the Cathedral remembers the mundane experience of its previous lives in the sea of the world (2.207-8). This shows Eliot's interest in metempsychosis or rebirth. The birth of the individual creature according to his or her last wish is described in the Prashna Upanishad (3.10).

Eliot uses the terms "river" and "the sea" as symbols for spirituality, peace, and liberation in Four Quartets. Purasu Balakrishnan notes that on the one hand "It [Four Quartets ] has been called the greatest philosophical poem of this century. . . . It is alive with Christian imagery and symbols such as the Annunciation, Communion, Good Friday, the Temptation of Christ, the Fire, the Dove, the Rose, the Lotus" but on the other hand, it "carries explicit references to BhagavadGita" (73). River and the sea are two forms of water. Eliot searches for water. The search for water is the symbol for the soul's search for the Essence in order to be free from materiality (samsara, bondage, worldly experiences) for liberation in terms of the Upanishad. Eliot compares the Self (Atman) existing inside human beings with the river and the Great Self (Brahman), which is omnipresent, with the sea. Therefore, he posits, "The river [Atman] is within us, the sea [Brahman] is all about us" ("Dry Salvages" 130). This belief is found in the Mundaka and Prashna Upanishads that indirectly compare Atman with the river and Brahman with the sea $(3.2 .8 ; 6.5)$.

Eliot uses "the still point" as a major symbol for Atman or Brahman. When one knows that "I have the Self and that Self is Brahman" (Mandukya 2, Brihadaranyaka 1.4.10) through self-realization, he or she becomes Brahman-"brahma veda brahmaiva bhavati" (Mundaka 3.2.9) and achieves 
liberation while alive. Therefore, Eliot asserts, in this sense of epistemological liberation (liberation through knowledge): "At the still point of the turning world. Neither flesh nor fleshless; / Neither from nor towards; at the still point, there the dance is, But neither arrest nor movement" ("Burnt Norton" II 119). Here, he uses the word "the dance" in the sense of the attainment of the extreme joy of "the still point" when one becomes One with "the still point." Stillness (nishchalata) helps to achieve the timeless "still point" and liberation. He realizes that he is one with Brahman that is full of paradoxical attributes. Therefore, he prays to Him, "Suffer [allow] me not to be separated / And let my cry come unto thee" ("Ash-Wednesday" 67).

Eliot establishes oneness between "the fire and the rose" to oppose duality and to support non-duality. Duality is one reason for our bondage or suffering. Therefore, he tries to seek spiritual unity in diversity in his umbrella or blanket-like metaphorical line: "the fire and the rose are one [and the same]" ("Little Gidding" V 145). The metaphorical line covers the entire meaning related to the interpretation of the non -dual philosophy. The line suggests oneness between the individual self (jivatma) and the Universal Self/the Supreme Self (Paramatma), or between everything and Brahman. The metaphorical line is close to what the Chhandogya Upanishad proclaims, "Everything is Brahman" (3.14.1). "The word "one" means the non-dual Absolute Brahman (the Universal Self) in terms of the Chhandogya (6.2.1) and Ishavasya (Shanti-Path 4) Upanishads. There is nothing else except Brahman. The person who sees differences between Brahman and all else goes from death to death over and over again (Katha 2.2.13; Brihadaranyaka 4.4.19).

In "The Dry Salvages" III, Eliot presents the theory of karmayoga as taught by Lord Krishna to Arjuna at the battlefield of Kurukshetra. Selfless karma performed without attachment not desiring for the achievement of its result liberates human being from the cycle of life and death. Therefore, Eliot reiterates the message of Lord Krishna as given in the Bhagavad-Gita 2.47: "And do not think of the fruit of action/ . . . But fare forward, voyagers" (134-35), which is influenced by the theory of unattached, selfless, or disinterested karma presented by the Ishavasya(1-2), Mundaka(3.1.4), and Shvetashvatara(6.4) Upanishads.

The ultimate goal of life's journey is to go beyond materiality and duality in order to achieve the original source ("the still point"), the source of perpetual peace and unbound happiness. The goal is to "attain the unread vision in the higher dream" for "the token of the word [Brahman] unheard, unspoken" ("Ash-Wednesday" 64), says Eliot. Therefore, he determines his journey motif:

We shall not cease from exploration.

And the end of all our exploring Will be to arrive where we started

And know the place for the first time. ("Little Gidding" V 145) But 
the original source of life (Brahman) could be attained only through inner experience, the inner transformation of ideas, and the selfrealization of what the Chhandogya Upanishad asserts, "tattvamasi" - that are you (6.8.7). Hence, Mary gives a wise counsel to Harry to

Be your real self, to do something for you

That you can only do for yourself.

What you need to alter is something inside you

Which you can change anywhere-here, as well as elsewhere. (Family Reunion 1.2.250) This idea is influenced by the Kena (2.5), Katha (1.3.14), and Brihadaranyaka (4.4.14) Upanishads, which assert that one oneself is Brahman but for having this knowledge, one must recognize his or her individual self as Brahman. We have consciousness, which is a proof of the existence of Brahman as the Aitareya Upanishad maintains that (pure) consciousness is Brahman-"prajnaanam brahma" (3.1.3).

Divine bliss comes while one is in touch with one's Self within heart or when one knows what the Brihadaranyaka Upanishad declares, "I am Brahman" (1.4.10), who is the witness of all the activities. But Harry feels unhappy because of "The degradation of being parted from my self, / From the self which persisted only as an eye, seeing" (Family Reunion 2.2.272). Hell is "emptiness, absence, separation from God" (Murder in the Cathedral 2.210). An individual is in hell until the person is a slave to his or her impure desires (i.e., lust, anger, avarice, attachment, delusion, pride, jealousy, passion, infatuation, and enmity) for sense gratification and has no knowledge of his or her Self (Atman or Brahman). In light of the Ishavasya Upanishad, the person who dies having no knowledge of Brahman is a suicider of his or her self and goes to hell (Ishavasya 3).

For a liberated soul, there is neither heaven nor hell. Though the Veda (Shruti, Nigam)discusses about the presence of heaven and hell and though reason (tarka or yukti) justifies it, yet they (heaven and hell) are not confirmed by our experience (anubhav or anubhooti). Our experience tells us that our good works make our life heaven and bad works hell. The Vedanta reasons that it is necessary for anything to be true to be supported by three things - the Veda, logic/reason, and experience. According to Shankar Vedanta, all projected or created things are not eternal. Hence, those apparent things are unreal (mithya). From this perspective also, heaven and hell are unreal, and this world, too, is unreal because they are the projections (creations) of Brahman. As Shankaracharya argues there is no world, it is mithya though we are perceiving it (Vivekachudamani 20), in the same sense there is neither heaven nor hell because there is no space-time-object(deshakala-vastu) in Brahman, or even if there is heaven or hell, all this is Brahman 
since there is nothing else except Brahman. All positions ("sthiti") are in space; all feelings ("bhaavanaa") are in time; all relations ("sambandha") are in objects (Khaptad Baba 210-12, 194). But all these entities (positions, space, feelings, time, relations, and objects) are temporary.

Wherever there is pleasure there is heaven whereas wherever there is pain there is hell. Pleasure and pain are on this earth. From this perspective, heaven and hell are on this earth. They might be somewhere up and down the earth respectively but our experiences do not prove them. Regarding the existence of hell or heaven, Andrew Brown argues, "Heaven and hell are a state of mind." The concept of hell, heaven or God is like the concept of the number zero, which has no physical reality in the external world, yet it (zero) exists in our imagination as an abstract thing to work for us in our experience. Abstract things, such as real bliss, or real anguish, are real, for them who have experienced them (The Guardian, online resource).

Regarding hell, in The Cocktail Party, Edward, after realizing the meaninglessness of his own and his wife's adultery, reveals to his wife Lavinia that one oneself is hell ("prison") if he does evil. Hell is alone because one alone is responsible for one's actions. One's relationship with others is temporary. They are merely projections (not real, not remaining forever). They merely come and go. They are like dream, simply the projection (a mental image viewed as reality, the act of perceiving a mental object as spatially and sensibly objective) of the mind; the dream is true until it lasts; only the Self is real, immortal, and eternal; the same Self is everywhere; or everything or everyone has the same Self; therefore, one cannot escape from one's Self to one's Self, a view of non-duality. One (the Self/Atman or the Great Self/Brahman) is without a second:

EDWARD. What is hell? Hell is oneself,

Hell is alone, the other figures in it

Merely projections. There is nothing to escape from [the Self]

And nothing to escape to [the Self]. One is always alone.

(1.3.342)

The word "One" means the non- dual Brahman in the Upanishad. Also, "One" means perfect, complete, and undivided (Brahman) in the Upanishad. For example, the Ishavasya Upanishad concludes that Brahman is Still ("anejat") and One ("ekam") (6).

In this context, Eliot declares his journey motif to search for the source of the Infinite bliss, that is Brahman-"Home [Brahman, also a symbol of peace and bliss] is where we start from" ("East Coker" 129) and, therefore, "We must be still and still moving / Into another intensity For a further union, a deeper communion. . . . ("East Coker" V 129) with "the still point." The Taittiriya Upanishad proclaims that bliss (or fullness) is Brahman-"aanando brahma" (3.6). The state of bliss is the state of 
liberation or that of the union with Brahman according to the Upanishad. All the dualities disappear at the state of bliss just as all kinds of rivers become one sea finally after merging into it (Mundaka 3.2.8). This is the state of nonduality. This state can be realized in life through effort, faith, self-enquiry ("Who am I?"“What is my true nature?"), self-knowledge, and selfrealization.

In this context, Eliot's writings are about man's spiritual journey for the search of the forgotten Self. They focus on the predicament of human being searching for liberation. Therefore, Eliot appeals for the reconstruction of the European mind in terms of its lost humanist thinking, religious concern, and spiritual spirit. For this reconstruction, he proposes, "There is only the fight to recover what has been lost / . . f for us, there is only the trying. / The rest is not our business" ("East Coker" V 128). For this reconstruction, especially for the realization of "the still point" (the Essence, Brahman) and the attainment of liberation, he indicates three paths - the path of selfless and disinterested action (karma), the path of devotion (Bhakti) and the path of knowledge (jnana). The expression of these three paths finds its presence in "prayer, observance, discipline, thought, and action" ("Dry Salvages" V 136). We can follow any path that ultimately leads to the same "still point." But "the still point" cannot be attained without the spirit of spirituality through reasoning or logic, five senses and notion either though they can serve as a secondary aid. So, Eliot argues:

If you came this way [of spirituality], Taking any route, starting from anywhere,

It would always be the same: you would have to put off Sense and notion. You are not here to verify, Instruct yourself, or inform curiosity

Or carry report. You are here to kneel

Where prayer has been valid. ("Little Gidding" 139)

Here, Eliot implies that it requires prayer, devotion, faith, and belief in spirituality, which enable us to have the realization of the Self, to have the knowledge of the Truth, and to have the perception of the Real while searching for "the still point." He also seems to imply that there are many paths to reach the Infinite Reality. As many faiths, so many paths. This type of belief in many paths leading to the same destination of the Essence is spiritual pluralism.

According to the Katha Upanishad, the five senses are turned outward ("paraanchi khaani"). Hence, they see only external matters, external bodies, and the external world but not the internal Self.

Therefore, we need to withdraw our eyes inward to see the inner Self (2.1.1) . In other words, it requires us to have the sixth sense (mind), 
and/or the third eye (spiritual eye), which is turned inward, in order to see "the still point" or the Infinite Reality.

Sir Henry Harcourt- Reilly (a Buddha-like character, who works as a consulting psychiatrist) illumines Celia that each way (the way of knowledge or the way of selfless action devoted to God) prescribes "its own duty." Then she asks, "Which way is better?" The reply given by him is: "Neither way is better. It is also necessary / To make a choice between them" (Cocktail Party 2.365). This idea of choosing either way, which ultimately leads to liberation, is supported by the Mundaka Upanishad, which confirms that all types of rivers finally enter and disappear into the ocean by destroying their names and forms, now being identified as the only name of the ocean. (3.2.8). However, the Ishavasya Upanishad expresses that Karma helps make life comfortable and easy to cross death; knowledge helps attain Brahman finally. Thus, we need both karma (avidya) and knowledge (vidya) for a balanced life (11) as a bird needs two wings to fly over the sky.

Eliot finally gives high importance to the immediate (aparoksha) path of knowledge, which he implies at the concluding line of his last poem "Little Gidding" V in Four Quartets as saying, "the fire and the rose are one [and the same]" (145) or "the way up is the way down / and the way forward is the way back" in "The Dry Salvages" III (134). The word "one" indicates the Brahman without a second in the Upanishad. The path of knowledge seeks to transcend materiality for realizing the Essence. To transcend materiality, Eliot gives first emphasis on the purification of the intention of our heart through devotion. "And all shall be well and / all manner of thing shall be well / by the purification of the motive / in the ground of our beseeching" ("Little Gidding" III 143). This idea of pure motive and devotion for the realization of the Essence is influenced by the Brihadaranyaka(4.4.5) and Chhandogya(1.1.10) Upanishads, which express that one gets fruits according to his or her motives and actions; if actions are done with knowledge, faith (shraddha), and yoga, they are more fruitful.

Desire is the root cause of all empirical existence. That is, desires are the seeds of rebirth. Desires create the world. The elimination of worldly desires can lead to the elevated and exalted state of the timeless "still point" (Atman/Brahman) and liberation before death. Mental or psychological detachment matters more than the physical disconnection from objects. Therefore, Eliot wishes, "The inner freedom from the practical desire. . . . a white light still and moving / Erhebung without motion, concentration. ..." ("Burnt Notion" II 119). This idea of eliminating desires or being without desires for attaining liberation and ecstasy is close to the Brihadaranyaka and Katha Upanishads, which express that the attainment of Brahman and bliss takes place when one reaches at the state of zero wishes and realizes one's identity with all as Brahman (4.3.21, 4.4.6-8; 2.3.14). In fact, where there is 
the sacrifice of desires, there is satisfaction; where there is satisfaction, there is the attainment of Brahman.

Forgetting the painful past and its unfulfilled cravings are more desirable than grooming them to make our long journey of life happy. Cravings, though sweet during the state of ignorance, finally deceive us in reality. Therefore, Eliot speaks through his character Agatha:

AGATHA. Relief from what happened

Is also relief from the unfulfilled craving

Flattered in sleep, and deceived in waking.

You have a long journey. (Family Reunion 2.2.277)

Spiritually speaking, those who are running after material prosperity and progress are asleep in darkness. And those who have self-knowledge are awakened ones. Besides, the words "sleep" and "waking" refer to unreality or ignorance, and reality or knowledge respectively. Life is a long journey. So, we need caution, consciousness, and conscience to be free sleep, darkness, or ignorance.

It is important to know first what ignorance is because if we know it, then we can get knowledge, which is a cure of all kinds of psychological, spiritual, and physical diseases or defects. Therefore, Eliot asserts, "In order to arrive what you do not know / you must go by a way which is ignorance" ("East Coker" III 127), and further maintains, "the lesson of ignorance, [is a treatment] of incurable diseases" (Family Reunion 2.2.281). This idea of reaching to knowledge through ignorance is influenced by neti neti (apophatic knowledge; negation; not this, not this) of the Brihadaranyaka(3.8.8, 4.4.22, 4.5.15) and Mandukya (7)

Upanishads. According to Khaptad Baba, neti neti usesnegative wordsto

describe Brahman beginning with $|\ni|$ or $|\mathrm{n}|$ sound in Sanskrit such as "anaadi" (eternal), "ananta"(infinite), "abhedya"(impenetrable),

"anaami"(nameless), "nirguna" (attributeless), "nishkriya"(inert),

"niranjana"(taintless), "nirlepa"(unsullied, stainless, unsmeared),

"niraamaya"(stainless), "avyakta" (unmanifest), "advaita"(non-dual, not two) and so on (247-48).

We can transcend materiality and attain the Essence (the still point," Brahman) through self-realization. To transcend materiality, we should walk on the path of spirituality. For this, we should be humble, renounce the world and its property and pleasure, or we should remain in abstention from physical and mental movements involving memory and desire, especially strong sexual desires, and enter the world of samadhi,the non-dual transcendental state of self-realization, through meditation. Therefore, Eliot appeals:

Descend lower, descend only

Into the world of perpetual solitude [samadhi, absorption], 
World not world, but that which is not world.

Internal darkness, deprivation

And destitution of all property,

Desiccation of the world of sense,

Evacuation of the world of fancy,

Inoperancy of the world of spirit:

This [renunciation] is the one way, and the other [asceticism] Is the same, not in movement

But abstention from movement: while the world moves In appetency, on its metalled ways

Of time past and time future ("Burnt Norton" III 120).

Here, the first two lines suggest that the goal of life is to attain "perpetual solitude," which is the non-dual state of nirvikalpa samadhi of "internal darkness." Samadhi is the state of absorption or immersion in Brahman or the achievement of sameness or identity with Him. In the state of nirvikalpa samadhi, "When the mind is conscious but conscious of nothing"("East Coker" III 126) with no triputiveda. That is, the distinction between the knower, the known and the knowledge disappers. During this state of nirvikalpa samadhi, the knower (seer, drasta, jiva) and the known (scene, drishya, Brahman) become One (Brahman), and the knower loses all his or her sense of being in existence and all his or her knowledge of this conscious process as well when one is free from the ignorance of one's true nature. In terms of the Mundaka Upanishad, nirvikalpa samadhi is the state of becoming Brahman after knowing It_- "brahmavid brahmaiva bhavati" (3.2.9). Eliot finally suggests that unless one walks on the path of renunciation or asceticism and has no desires, especially sexual ones, he cannot be free from the cycle of life and death. The path of renunciation and asceticism belong to the path of knowledge.

It is not so easy to walk on this path of knowledge. Therefore, Reilly admonishes his patients, "Go in peace. / And work out your salvation with diligence" (Cocktail Party 2.357). It is difficult to attain "salvation" or moksha; it is like walking on the sharp edge of a razor (but once one attains it, one never comes back to this mortal world). Therefore, arise, awake, and go to the best spiritual teacher to know the Supreme Reality for liberation (Katha 1.3.14). Actually, the best teacher teaches that true happiness lies within us. We must find it in our own Self. Though it is difficult to find happiness in ourselves, it is impossible to find it anywhere else. The admonition of Reilly to his patients might be read as Buddha's deathbed sermon to his disciples. As John Powers writes Buddha delivered his final sermon as: "Monks, all compounded things are subject to decay and 
disintegration. Work out your own salvations with diligence!" (56) as descried in "Discourses of the Great Final Nirvana [Mahaparinibbana-sutta]" (61).

In fact, worldly attractions are traps. Therefore, Fourth Tempter cautions Archbishop Thomas Becket, "Hooks have been baited with morsels of the past. / Wantonness is weakness" (Murder in the Cathedral 1.190). Becket renounces Four Tempters' temptations. Besides the Upanishadic reading, his victory over temptations might be read from the Buddhist perspective. As A. N. Dwivedi remarks, "The Buddhist gospel of renunciation emerges clearly in this [Murder in the Cathedral] tension-ridden play. Becket, the protagonist seeks to put an end to the slightest desire for self-glory and becomes completely oblivious of self-security. In his Christian guise, he verily lives through the Buddhist concept of renunciation" (178). In reality, desire for lust, power, or pleasure (kama) is a cause of despair. So, Mary makes Harry aware of ".. . joy [which] is a kind of pain" (Family Reunion 1.2.251).

As suggested earlier, Eliot gives most emphasis on the non-dual knowledge of "the still point" (Brahman) to transcend materiality for realizing the Essence. The darkness of duality traps in the cycle of life and death whereas the knowledge of non-duality liberates from that cycle. Therefore, Eliot advises us, as mentioned before, to hold the idea of "the fire and the rose are one" echoing the Chhandogya Upanishad, which expresses that all this world is Brahman (3.14.1), and the Ishavasya Upanishad, which expresses that this whole world is God- "eesha" (1). He uses the term "fire" more often in the sense of knowledge, which is a key to the liberation of the individual self from the fire of mundane desires and the cycle of life and death. Therefore, he confirms, "The only hope, or else despair / Lies in the choice of pyre [purity of life] or pyre [worldly desires] - / to be redeemed from fire [of desires] by fire [of knowledge]" ("Little Gidding" IV 144), echoing the Ishavasya Upanishad, which expresses that knowledge (of Brahman) helps achieve immortality_"vidyayaa amritam ashnute" (11).

\section{Conclusion}

The goal of life is to return there (i.e., "Home," a symbol of Brahman, Everlasting Peace and, Unbound Bliss) from where we came. Therefore, we need to return home to Brahman. In other words, the original source of life is Brahman ("the still point"), who is the final destination of life's cosmic or spiritual journey. The unification of Atman (the Self) with Brahman (the Universal Self) is necessary for getting perpetual peace and unbound happiness. Just as rivers flow impatiently to get its original source, the sea, and become still only when they get it, so also the individual selves (jivatmas) become peaceful and happy only when they attain "the still point"-Brahman or moksha (final liberation from material existence). 
Unless attaining "the still point," the Wheel of life and death does not stop. Our desires, thoughts, determinations, karma, and habits cause the Wheel of life and death to move. We grow old but desires never. Therefore, we must attempt several times, over many lifetimes, to attain Brahman either through the path of selfless action, or through devotion, or through spiritual knowledge. Among these three paths, Eliot prefers the path of knowledge because it can make us realize Brahman immediately in this life whereas the other two paths can lead us to Brahman but progressively or indirectly only after death. When we become free from the myriads of mundane desires (i.e., lust, anger, avarice, attachment, delusion, pride, jealousy, passion, infatuation, and enmity), we become free from the bondage of samsara (materiality, transmigration, bondage, physical desires). Then the Wheel of life and death stops. We are in hell or prison until we are slaves to our desires for our sense gratification and have no knowledge of our divine Self (AtmanBrahman). This is a key to enlightenment. Enlightenment is not possible from a strict adherence to duality, one of the main causes of human suffering. The root cause of duality, differences, suffering, anguish, pain or unsatisfactoriness is ignorance. The cause of ignorance is lack of spiritual knowledge. Once we have self-knowledge and self- realization, we understand that Atman, Brahman, and the whole creation are one. Then the darkness of ignorance disappears automatically. This whole idea is the essence of the Upanishads, which we find in Eliot's writings.

The significance of this paper within the context of existing scholarship lies in its introduction to the new knowledge that Eliot's poems and plays could be extensively interpreted by finding the essence of the Upanishad in his texts. Practically, the knowledge of the essence of the Upanishad can help us know the mystery of life and death, and Atman and Brahman, and attain liberation from all kinds of suffering and misery, and from the cycle of life and death as well. Self-knowledge is important and self-realization is more important than that, which Eliot wants to stress in his writings. He rebuts the dualistic thinking of the Western mind and instead confirms the non-dualistic thinking of the Upanishad of the Eastern mind through his writings. This is his specialty.

\section{Works Cited}

Baba, Khaptad. Vedanta-Vijnana [The Science of Vedanta]. Edited by Shivagopal Risal, Khaptad Ashrama Prakashan Samiti, 2052 BS.

Balakrishnan, Purasu. "An Indian View of T.S. Eliot's 'Four Quartets "The American Scholar, vol. 60, no. 1, The Phi Beta Kappa Society, Winter 1991, pp. 73-89. JSTOR, www.jstor.org/stable/41211867?seq=1. Accessed 23 Dec. 2000. Brown, Andrew. "No Wonder the Pope has Caused Confusion. 
Heaven and Hell are a State of Mind."The Guardian Weekly, www.theguardian. com/ commentisfree/2018/apr/02/pope-francisheaven-hell-eternity. Accessed 19 Dec. 2020.

Dwivedi, A. N. T.S. Eliot: A Critical Study. Atlantic Publishers and Distributors, 2002.

Eliot, T. S. The Complete Poems and Plays of T. S. Eliot: 1909-1950. Harcourt Brace \& Company, 1967.

Gambhirananda, Swami, translator. Eight Upanishads: With the Commentary of Shankaracharya, vol. 1 \& 2, Advaita Ashrama, 2016.

Oldmeadow, Harry. Journeys East: 2oth Century Western Encounters with Eastern Religious Traditions. World Wisdom, Inc., 2004.

Perl, Jeffrey M., and Andrew P. Tuck. "The Hidden Advantage of Tradition: On the Significance of T. S. Eliot's Indic studies "Philosophy East and West, vol. 35, no. 2, U of Hawai'i P, Apr. 1985, pp. 115-31. JSTOR, www.jstor.org/stable/1399046. Accessed 23 Dec. 2000.

Powers, John. Introduction to Tibetan Buddhism. Snow Lion Publications, 2007.

Radhakrishnan, S., editor and translator. The Principal Upanishads. HarperCollins Publishers, 2012.

Shankaracharya, Sri. Sri Shankaracharya's Vivekachudamani [Shankaracharaya's Crest-Jewel of Discrimination]. Translated by Swami Madhavananda, Advaita Ashrama, 2009.

Weinberger, Eliot. "Memory, Karma, Smell."Two Essays, Scholarly Journals, no. 36, Spring 1995, pp. 52-57. ProQuest, www.search.proquest.com/docview/884342446?pq-

origsite $=$ gscholar $\&$ fromopenview $=$ true. Accessed 23 Dec. 2020. 